\title{
CANNULATED SCREWS IN THE TREATMENT OF UNICAMERAL BONE CYSTS IN HUMERUS AND FEMUR - ANALYSIS OF THE IMPACT OF DIFFERENT VARIABLES ON THE HEALING PROCESS
}

\author{
VLOGA KANULIRANIH VIJAKOV PRI ZDRAVLJENJU \\ ENOSTAVNE KOSTNE CISTE V NADLAHTNICI IN STEGNENICI - \\ ANALIZA VPLIVA RAZLIČNIH SPREMENLJIVK NA CELJENJE
}

\author{
Lovro Suhodolčan ${ }^{*}$, Velimir Bole ${ }^{2}$, Janez Brecelj ${ }^{1}$ \\ ${ }^{1}$ Department of Orthopaedic Surgery of the Ljubljana University Medical Centre, Zaloška 9, 1000 Ljubljana, Slovenia \\ ${ }^{2}$ EIPF, Ekonomski inštitut, d.o.o., Einspielerjeva 6, 1000 Ljubljana, Slovenia \\ Prejem rokopisa - received: 2019-05-28; sprejem za objavo - accepted for publication: 2019-09-07
}

doi: $10.17222 /$ mit.2019.116

\begin{abstract}
A unicameral bone cyst (UBC) is a benign lesion involving the metaphyseal-diaphyseal region of long bones. Intervention has been advocated to prevent fractures, especially in the weight-bearing long bones. Minimally aggressive surgical methods in the treatment of these cysts with the intention to reduce long-term morbidity were proposed recently. The purpose of this investigation was to evaluate the different factors that influence the healing rate of a UBC treated only with cannulated screws. Between 2000 and 2015 a total of 66 children with UBC localized in humerus or femur were treated with the continuous decompression method using cannulated screws. We analyzed the impact of the age of the patient, gender, localization of the cyst, time between surgeries and the number of treatments in an attempt to predict the treatment outcome. The mean radiological follow-up in the HUMERUS group was 50.6 months, and in the FEMUR group 31.3 months. The success rate after the first and the second intervention in the HUMERUS group was $39 \%$ and $71 \%$, respectively, and in the FEMUR group $71 \%$ and $100 \%$, respectively. In the estimated logit model four characteristics have a statistically significant positive effect on the healing rate: greater age of the patient, male sex, localization in femur and no third surgery intervention incidence. However, when the third intervention is indicated, we suggest using a more aggressive surgical approach.

Keywords: unicameral bone cyst, decompression, cannulated screw
\end{abstract}

Enostavna kostna cista je benigna lezija kosti, ki leži v metafizno-diafizni regiji dolgih kosti. Pri nosilnih kosteh izvajamo kirurške posege, da se izognemo patološkim zlomom. V zadnjem času so na voljo minimalno invazivni posegi, ki zmanjšajo možnost za zaplete. Namen študije je bilo oceniti različne dejavnike, ki vplivajo na celjenje kostnih cist pri zdravljenju s kanuliranimi vijaki. Med leti 2000 in 2015 smo zdravili 66 otrok z enostavno kostno cisto, locirano v nadlahtnici ali stegnenici. Vse smo zdravili z vstavitvijo kanuliranih vijakov. Da bi ocenili učinek takšnega zdravljenja, smo analizirali vpliv starosti bolnika, spola, lokacije ciste, časovnega intervala med posameznimi posegi in celotnega števila posegov. Srednja opazovana doba v skupini (HUMERUS-nadlahtnica) je znašala 50,6 mesecev, v skupini (FEMUR-stegnenica) pa 31,3 mesecev. Odstotek zacelitve je po prvem in drugem posegu v skupini HUMERUS znašal $39 \%$ oziroma $71 \%$, v skupini FEMUR pa $71 \%$ oziroma $100 \%$. Z uporabo Logit modela smo ugotovili štiri statistično pomembne dejavnike, ki pozitivno vplivajo na celjenje: višja starost bolnika, moški spol, prisotnost ciste v stegnenici in zacelitev že po dveh kirurških posegih. V kolikor zdravljenje kostne ciste $\mathrm{z}$ uporabo kanuliranih vijakov po prvih dveh posegih ni uspešno, se v nadaljevanju svetuje bolj agresivno kirurško zdravljenje.

Ključne besede: enostavna kostna cista, dekompresija, kanuliran vijak

\section{INTRODUCTION}

A unicameral bone cyst (UBC), also known as a solitary or simple bone cyst, is a benign lesion involving the metaphyseal-diaphyseal region of long bones, especially in the humerus and femur, in the first two decades of life, with a peak age of around ten years. ${ }^{1,2}$ The cyst's expansion causes thinning of the bone cortex, which often results in pathological fractures., ${ }^{3,4}$ Despite their benign nature, these cysts require treatment to prevent pathologic fractures, prolonged restriction of activities, and deformities or even the shortening of long

*Corresponding author's e-mail:

lovro.suhodolcan@kclj.si (Lovro Suhodolčan) bones. ${ }^{5,6}$ Intervention has been advocated to prevent fractures and their related complications, especially in the weight-bearing long bones. Cysts in the metaphysys near the growth plate are usually bulging; they recur more often and are defined as active. During bone growth they "migrate" towards the diaphyseal region and change to latent. For a UBC located in the femur, surgical intervention is recommended because of the high-stress, weight-bearing area of the bone. ${ }^{7}$ Although open currettage and autologous bone grafting along with implant augmentation have been conventionally used as the definitive treatment for a UBC located in the weight-bearing bone, such aggressive surgical methods are problematic because of long-term morbidity. 8,9 An UBC seems to be a dysplastic or reactive lesion rather 
than a true tumor. It is probably caused by venous circulation disorder in the cancellous bone. Bone resorbtion occurs due to a blockage in the venous flow, increasing pressure, and an elevated inflammatory protein level in the intracystic fluid. ${ }^{10-12}$ Since venous obstruction may play an important role in the pathogenesis of a UBC, various minimally invasive surgical procedures for UBCs were proposed. ${ }^{13,14}$ Kirschner wires, drilling, flexible intramedullary nails and cannulated screws have been used to provide continuous decompression as a treatment option. ${ }^{15-21}$

A statistical analysis of our results has been conducted to evaluate different factors that influence the healing rate of a UBC treated only with cannulated screws. We therefore hypothesized that the healing rates are higher in older patients. Furthermore, that sex and localization of the cyst do not affect the healing rate. We also analyzed the effect of a third surgery on the healing probability. Considering our study as well as other recent studies, we propose guidelines for the treatment of a UBC located in long bones.

\section{EXPERIMENTAL PART}

\subsection{Patients}

Our retrospective study included 83 patients with UBC, which have been treated at our institution between 2000 and 2015. The inclusion criteria for this study was a UBC localized in the humerus or femur treated exclusively with thr continuous decompression method using cannulated screws. All other anatomical sites and other treatment modalities were excluded. Some 66 patients met these criteria and were available for evaluation. They were divided into two groups according to the location of the UBC. The HUMERUS group included 52 patients where the cyst was located in the humerus. The FEMUR group included 14 patients where the cyst was located in the femur. Demographic data for each group is presented in Table $\mathbf{1}$.

Table 1: Details of cysts in the HUMERUS and FEMUR groups (number and percentage)

\begin{tabular}{|l|c|c|}
\hline \multirow{2}{*}{} & \begin{tabular}{c} 
HUMERUS \\
group \\
\cline { 2 - 3 }
\end{tabular} & FEMUR group \\
\hline No. of men & $39(75 \%)$ & $14(100 \%)$ \\
\hline $\begin{array}{l}\text { No. of pre-existing } \\
\text { pathological fractures }\end{array}$ & $50(96.2 \%)$ & $7(50 \%)$ \\
\hline No. of active cysts & $9(17.3 \%)$ & $10(71.4 \%)$ \\
\hline $\begin{array}{l}\text { Age at first treatment: } \\
\text { years(mean) } \pm S D \text { (range) }\end{array}$ & $\begin{array}{c}10.9 \pm 2.8 \\
(4.4-16.9)\end{array}$ & $\begin{array}{c}8.79 \pm 3.9 \\
(2.2-15.3)\end{array}$ \\
\hline
\end{tabular}

\subsection{Methods - surgical treatment}

An accurate description of the cannulated screw and its insertion technique were already described by a senior author. ${ }^{15}$ The continuous decompression of bone titanium screw was designed and first used by the senior author in

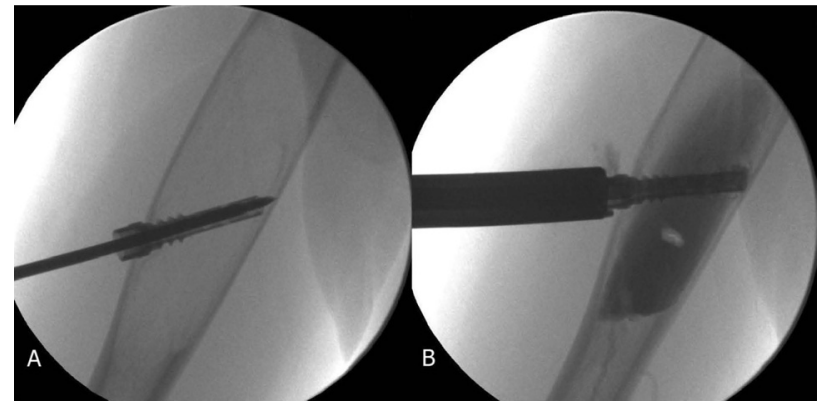

Figure 1: A) Insertion of the screw, B) a single cavity determined after cystogram

1995. Its shape permits the use of a special targeting system for screw insertion (Heli Pro ${ }^{\circledR}$ ). Under fluoroscopic guidance a 2-mm K-wire was drilled through a 5-mm skin incision, advanced through the centre of the cyst cavity and fixed to the opposite cortex. It was left in place throughout the procedure to serve as a guiding device. Using cannulated instrumentation, the proximal cortex was perforated with a 3.5/2.2-mm cannulated drill, and a 4.5/2.6-mm C.D.B. screw was inserted over the K-wire. The cyst was aspirated through the screw, and a cystogram was performed using a $50 \%$ Iohexol (Omnipaque) solution to determine whether there were separate cavities (Figure 1).

\subsection{Radiological assessment}

The activities of the cysts at first visit and a postoperative evaluation of the results were evaluated according to the radiological criteria described by $\mathrm{C}$. $\mathrm{H}$. Chang 22 (Table 2). The treatment was considered to be a failure if a subsequent procedure was undertaken or indicated (grade 3 or 4 according to C. H. Chang ${ }^{22}$ ). Cysts rated as radiologically healed or healed with a defect (grade 1 or 2 according to C. H. Chang ${ }^{22}$ ) were regarded as having been successfully treated. The model a two-states patient status variable was constructed from the original four-states variable. Cysts rated grade 1 or 2 according to $\mathrm{C}$. H. Chang ${ }^{22}$ were marked with the value 0 , cysts rated grade 3 or 4 were marked with value 1 .

Table 2: C. H. Chang ${ }^{22}$ classification of the radiological results in unicameral bone cysts

\begin{tabular}{|l|l|}
\hline Classification & \multicolumn{1}{c|}{ Description } \\
\hline 1. Healed & $\begin{array}{l}\text { Cyst filled by the formation of new bone } \\
\text { with or without small static radiolucent } \\
\text { area(s) less than 1 cm in size }\end{array}$ \\
\hline $\begin{array}{l}\text { 2. Healing with } \\
\text { defect }\end{array}$ & $\begin{array}{l}\text { Static, radiolucent area(s), less than 50\% of } \\
\text { the diameter of the bone with adequate } \\
\text { cortical thickness to resist fracture }\end{array}$ \\
\hline $\begin{array}{l}\text { 3. Persistent } \\
\text { cyst }\end{array}$ & $\begin{array}{l}\text { A radiolucent area greater than 50\% of the } \\
\text { bone diameter, and a thin cortical rim. No } \\
\text { increase in cyst size. Continued restriction } \\
\text { of activity or repeated treatment required }\end{array}$ \\
\hline $\begin{array}{l}\text { 4. Recurrent } \\
\text { cyst }\end{array}$ & $\begin{array}{l}\text { Cyst recurring in a previously obliterated } \\
\text { area, or a residual radiolucent area that has } \\
\text { increased in size }\end{array}$ \\
\hline
\end{tabular}




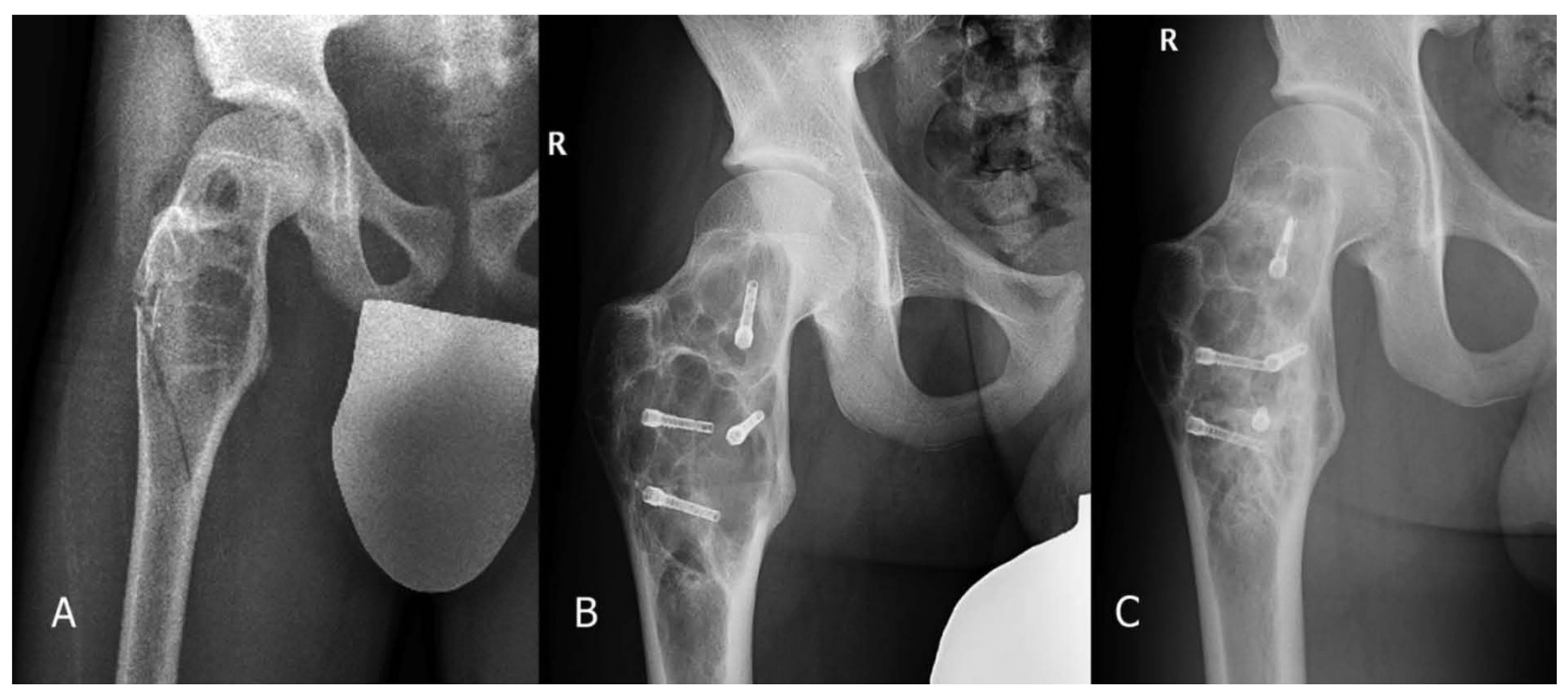

Figure 2: A) Femoral cyst with pathological fracture at the time of diagnosis, followed by 5-week imobilisation; B) 12 months after first operation; C) An additional screw has been added-the remaining screws were cleaned of fibrosis; 22 months after the second operation the cyst is healed.

\subsection{Follow-up}

As a standard, radiographs were taken at the 2nd, 4th, 6th, 12th months after the procedure and later every 6-8 months, to the end of growth (Figure 2). The status of

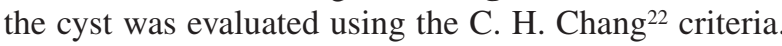

\subsection{Statistical analysis}

Several factors were studied for their impact on the outcome of the treatment. For every patient, data on age, sex and localization of the cysts were available. In addition, at each patient visit, several additional characteristics of the patient were recorded: activity of the cyst, months after the first surgery intervention, presence of previous pathological fracture and cumulative number of surgery interventions. The data were analyzed using the Stata/SE 12.1 for Windows (Stata Corporation, USA) software program. Patient status was modelled by means of logit regression using the time span (in months) after the first surgery intervention, age, sex, localization, activity of the cyst and dummy variables for the second and third surgery interventions as covariates. The model was estimated using 241 complete observations on the treatment of 66 patients. The presented effects on the healing rate are tested using the Wald-type test for nonlinear hypotheses. The P-values are calculated using the delta method. All values of $P<0.1$ were considered to indicate statistical significance.

\section{RESULTS}

Empirical evidence comprises 241 observations on 66 patients. Each observation pertains to a single patient at each visit. At every visit, control of the patient status was documented. If necessary, at such visits additional surgery intervention was indicated. No intraoperative or perioperative complication or pathological fracture at the site of the screw during the early bone-healing stage were noted. The screws that broke during removal, because of overgrowth of the screw shank with the new bone, were left in place. All pre-existing pathological fractures of the humerus were treated conservatively with a functional brace. Pre-existing pathological femoral fractures were treated mostly conservatively. In two cases, osteosyntesis of the femoral shaft using an LCP plate as well as cannulated screws were inserted.

The mean radiological follow-up in the HUMERUS group was 50.6 \pm 2.6 (range 12-134) months, and in the FEMUR group $31.3 \pm 2.4$ (12-113) months. The success rates after the first and the second intervention are shown in Figure 3.

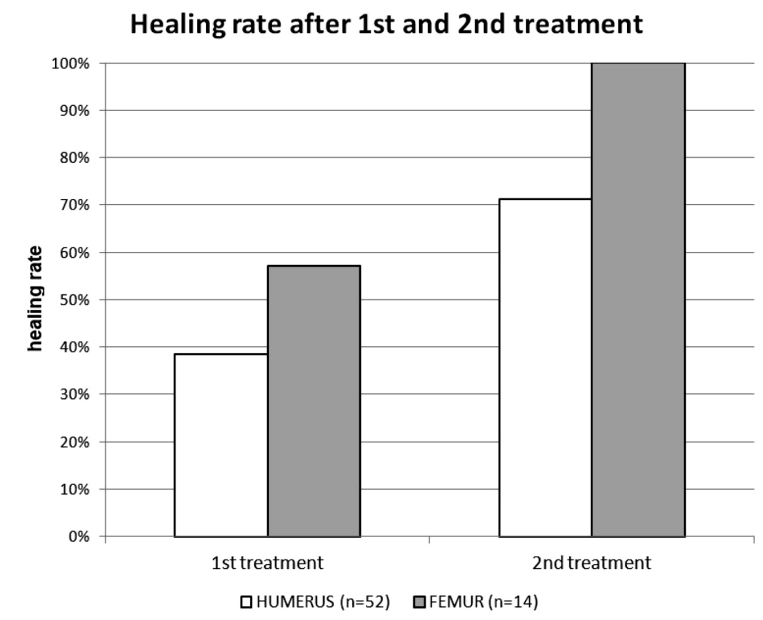

Figure 3: Healing rate in the HUMERUS and FEMUR groups after the first and the second procedures. Duration between the 1 st and 2 nd treatment in the HUMERUS group was 16.4 1 .1 months (range 3-60) and 19.14 \pm 1.2 months (range 4-39) in the FEMUR group 


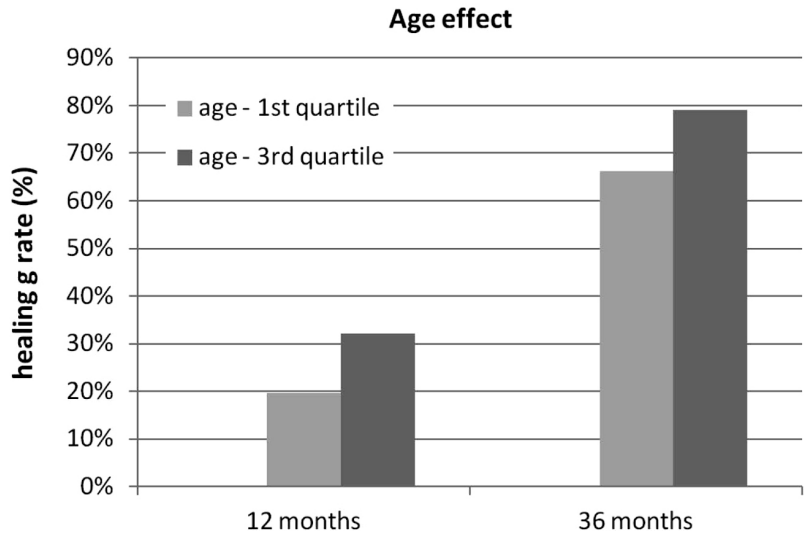

Figure 4: Statistically significant better healing rates were observed in the older group (third age quartile - 153 months old) relative to younger patients (first age quartile - 98 months old) (12 $\mathrm{m} p=0.23$; $36 \mathrm{~m} p=0.00)$

Analysed factor effects on the healing rates after the first and third years are given in Figures $\mathbf{4}$ to $\mathbf{7}$.

\section{DISCUSSION}

The widely accepted theory is that a focal defect in metaphyseal remodeling leads to venous obstruction, that results in increased intraosseous pressure. As a consequence we observe the expansion of the cyst size, which directs the treatment options. ${ }^{13}$ The trend is towards surgery, which diminishes the internal cyst pressure. The main indication for treatment of a UBC is the fracture risk. ${ }^{10}$ None of the treatment options guarantee a cure, except wide resection, which has been abandoned. The protocol for the best treatment method for a UBC located in the weight-bearing long bones has not been established yet. For that reason, the least aggressive techniques should be applied, with as little damage to the cortical bone as possible, in order to reduce fracture risk. Significant differences in success rates between various treatments can be explained by the morphological variation of bone cysts, as stated by $\mathbf{M}$. Amling. ${ }^{23}$ According to L. C. Johnson, ${ }^{24}$ the thickness of the cyst wall may vary from a few micrometers to $1 \mathrm{~cm}$.

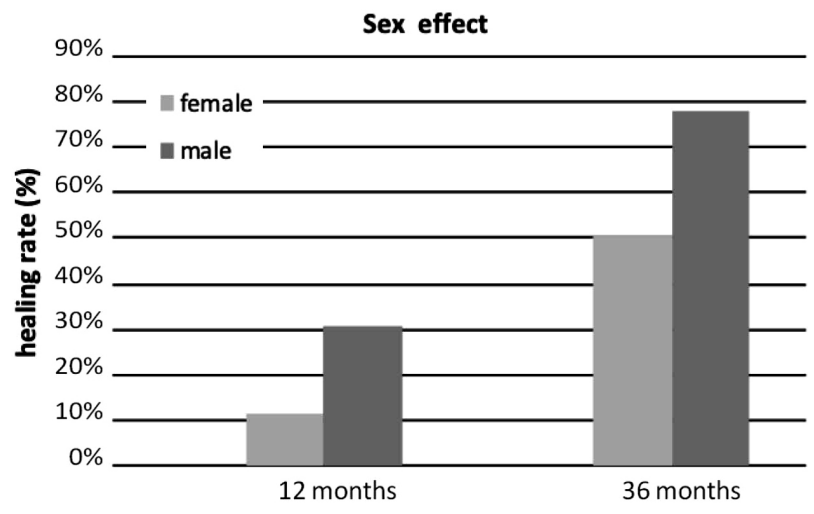

Figure 5: Strong significance was observed when comparing healing rates in the female group according to the male group in favor of the latter $(12 \mathrm{~m} p=0.13 ; 36 \mathrm{~m} p=0.08)$

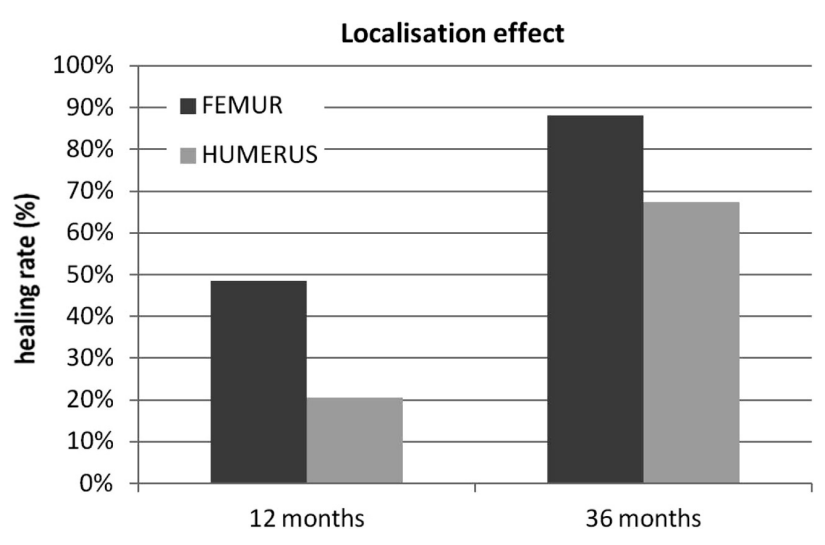

Figure 6: Significantly higher healing rate was noted in the FEMUR group. (12 $\mathrm{m} p=0.10 ; 36 \mathrm{~m} p=0.04)$

S. Komiya et al. ${ }^{25}$ found an enhanced bone-resorption activity due to elevated prostaglandin-E2, interleukin- $1 \beta$, and gelatinase content in the cyst fluid.. Furthermore, J. $\mathrm{Yu}^{26}$ et al. observed a different apoptosis response of UBC membrane cells to zoledronate with regards to trabecular bone cells. There is no consensus regarding the best treatment in proximal femoral neck lesions. Some authors suggest open surgery with osteosynthesis, which should be adapted to the patient's age, conserving the growth plate and allowing normal growth. ${ }^{10,27}$ A less aggressive approach to stabilize femoral neck fracture includes conservative treatment, which enables fusion and in some cases cyst ossification. The actual cyst is then treated after consolidation of the fracture if it does not heal spontaneously. Minimally invasive techniques such as intra-lesional steroid or bone-marrow injection have been used with variable success rates. Long-term follow up revealed the need for multiple injections and a high recurrence rate (up to $88 \%$ ). The treatment was ineffective for cysts in the weight-bearing bones. ${ }^{20}$ Further attempts to increase the healing potential included a decompression treatment with multiple drill-holes. ${ }^{16,25}$ In order to prevent premature healing of the drill holes,

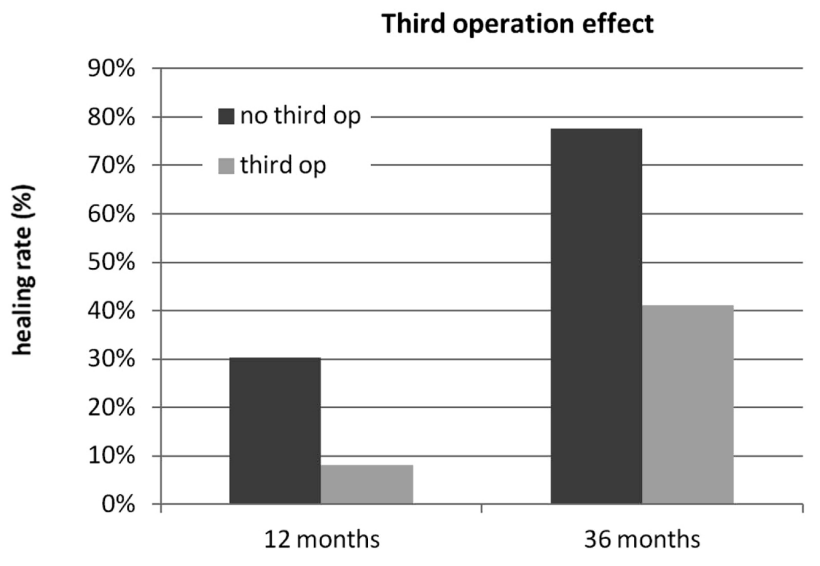

Figure 7: Effect of third or subsequent procedures is significantly weaker in comparison to the first and second operations $(12 \mathrm{~m} p=$ $0.16 ; 36 \mathrm{~m} p=0.06$ ) 
4.5-mm cannulated cortical screws that allowed continuous decompression of the UBC were proposed..$^{28} \mathrm{In}$ the early postoperative period, a strong tendency for UBC consolidation was noted, but the cysts recurred, and a proliferation of the fibrous tissue that blocks the tunnel was observed. Based on that experience, we therefore developed a special cannulated screw, which showed significantly better results than open curettage with bone grafting and steroid injections in our previously reported series.

A. Roposch et al. ${ }^{20}$ used flexible intramedullary nailing to treat a UBC located in neck and greater trochanter of the femur. In their series, 11 out of 12 cysts healed within a mean period of 38.3 months; 1 case needed additional plate fixation because of the loss of reduction, and 2 cases needed a nail exchange. ${ }^{20,29} \mathrm{~J}$. J. Masquijo et al. ${ }^{30}$ reported 48 patients treated with intramedullary nailing for UBC. In their series 19 patients had the UBC of the proximal femur, 24 cysts were located in a proximal humerus, and 2 in a humeral shaft. They observed higher healing rates in humeral versus femoral cysts $(92.3 \%$ versus $84.2 \%)$. In $8.9 \%$ of patients, replacement of the nail was performed. H.-Y. Hou et al. ${ }^{31}$ presented a series of 40 UBCs involving a long bone of the upper or lower extremity. High healing rates $(92 \%)$ were noted in a group where minimally invasive curettage, ethanol cauterisation, disruption of the cystic boundary with curved impactors, insertion of a synthetic calcium sulfate bone-graft substitute, and placement of the cannulated screw to provide drainage was performed. Recently, there has been a report of endoscopic currettage of the cyst of the proximal femur and injection of a bone substitute. The technique is technically demanding and should be reserved for recurrent cases. ${ }^{8}$

In our series of 14 patients with femur lesion the success rate after the second intervention using cannulated screw was $100 \%$ and there were no cases of late pathological fractures. Based on our experience, insertion of the cannulated screw in the long bones is a simple procedure with minimal negative impact on bone integrity and can be done as a day-case surgery. There are almost no associated risks regarding surgical site infection. Furthermore, no implant rejection was observed, as the screw is biocompatible and no bone substitute is inserted. No pain or functional limitations have been reported. Our minimally invasive technique can be used even in (recurrent) multi-loculated cysts. We have to emphasize that there are some cases of a UBC in the weight-bearing bones, where there is still no optimal treatment. In cases with a pathologic fracture of the large proximal femoral UBC, osteosynthesis with a plate, a dynamic hip screw or intramedullary nail is not possible, as it can compromise the growth plate. Therefore, a more conservative approach is suggested; it includes immobilization in a cast, and no weight bearing for up to $8-10$ weeks. When consolidation of the fracture is achieved, cannulated screws and a supporting plate should be inserted in a manner such that the growth cartilage is preserved.

We noted several limitations in this study. Due to the retrospective character of the study, data completeness and data quality usually have a lower level than in prospective clinical studies. All the humeral pathologic fractures caused by UBC were included in this study (not only proximal fractures or humeral shaft fractures). Also, there is a relatively small number of patients included in the FEMUR group.

\section{CONCLUSIONS}

The results of the statistical analysis of the influence of different factors on the healing probability are in favor of male patients, elder ones, those with the cyst located in the femur and those who needed two procedures at most - the necessity for the third intervention deteriorates the healing probability in the following months. However, when the third intervention is indicated, we suggest using a more aggressive surgical approach, as presented by H.-Y. Hou. ${ }^{31}$

\section{Acknowledgment}

This work was carried out within the framework of Department of Orthopaedic Surgery University Medical Centre Ljubljana, with no extra funding. No benefits in any form have been received or will be received from a commercial party related directly or indirectly to the subject of this article.

\section{REFERENCES}

${ }^{1}$ R.Virchow, Uber die Bildung von Knochencysten, Berlin: S-B Akad. Wiss., (1876), 369-81

${ }^{2}$ H. S. Cho, J. H. Oh, H. S. Kim, H. G. Kang, S. H. Lee, Unicameral bone cysts: a comparison of injection of steroid and grafting with autologous bone marrow, J. Bone Joint Surg. Br. 89 (2007), 222-226, doi:10.1302/0301-620X.89B2.18116

${ }^{3}$ J. I. Ahn, J. S. Park, Pathological fractures secondary to unicameral bone cyst, Int. Orthop. 18 (1994); 20-22, doi:10.1007/bf00180173

${ }^{4}$ F. H. Norman-Taylor, A. Hashemi-Nejad, B. L. Gillingham, D. Stevens, W. G. Cole, Risk of refracture through unicameral bone cysts of the proximal femur, J. Pediatr. Orthop., 22 (2002), 249-254

${ }^{5}$ M. Campanacci, R. Capanna, P. Picci, Unicameral and aneurysmal bone cysts, Clin. Orthop. Relat. Res., 204 (1986), 25-36

${ }^{6}$ F. Lokiec, E. Ezra, O. Khermosh, S. Wientroub, Simple bone cysts treated by percutaneous autologous marrow grafting, J. Bone Joint Surg. Br., 78 (1996), 934-937

${ }^{7}$ R. M. Wilkins, Unicameral bone cysts, J. Am. Acad. Orthop. Surg., 4 (2000), 217-224

${ }^{8}$ W. Miyamoto, M. Takao, Y. Yasui, S. Miki, T. Matsushita, Endoscopic Surgery for Symptomatic Unicameral Bone Cyst of the Proximal Femur, Arthrosc. Tech., 2 (2013), 467-471, doi:10.1016/j.eats. 2013.07.001

${ }^{9}$ B. Mavčič, V. Saraph, M. M. Gilg, M. Bergovec, J. Brecelj, A. J. Leithner, Comparison of three surgical treatment options for unicameral bone cysts in humerus, Pediatr. Orthop. B., 28 (2019), 51-56, doi:10.1097/BPB.0000000000000518 


\section{SUHODOLČAN et al.: CANNULATED SCREWS IN THE TREATMENT OF UNICAMERAL BONE CYSTS ...}

${ }^{10}$ E. Mascard, A. Gomez-Brouchet, K. Lambot, Bone cysts: unicameral and aneurysmal bone cyst, Orthop. Traumatol. Surg. Res., 101 (2015), 119-127, doi:10.1016/j.otsr.2014.06.031

${ }^{11}$ P. L. Docquier, Kyste osseux essential, EMC, Elsevier Masson SAS, 2011

${ }^{12}$ J. V. Gentile, C. R. Weinert, J. A. Schlechter, Treatment of unicameral bone cysts in pediatric patients with an injectable regenerative graft: a preliminary report, J. Pediatr. Orthop., 33 (2013), 254-261, doi:10.1097/BPO.0b013e318285c56c

${ }^{13}$ J. Cohen, Etiology of simple bone cyst, J. Bone Joint Surg. Am., 52 (1970), 1493-1497

${ }^{14}$ M. Chigira, S. Maehara, S. Arita, S. E. Udagawa, The etiology and treatment of simple bone cysts, J Bone Joint Surg. Br., 65 (1983) 633-637

${ }^{15}$ J. Brecelj, L. Suhodolcan, Continuous decompression of unicameral bone cyst with cannulated screws: a comparative study, J. Pediatr. Orthop. B., 16 (2007) 367-372, doi:10.1097/BPB. 0b013e32826d1ad6

${ }^{16}$ T. Shinozaki, S. Arita, H. Watanabe, M. Chigira, Simple bone cysts treated by multiple drill-holes. 23 cysts followed 2-10 years, Acta Orthop. Scand., 67 (1996) 288-290

${ }^{17}$ A. Ekkernkamp, G. Muhr, A. Lies, Continuous decompression. A new method in the treatment of juvenile bone cysts, Unfallchirurg, 93 (1990) 539-543

${ }^{18}$ H. Tsuchiya, M. E. Abdel-Wanis, L. Uehara, K. Tomita, Y. Takagi, H. Yasutake, Cannulation of simple bone cysts, J. Bone Joint Surg. Br., 84 (2002), 245-248

${ }^{19}$ P. Catier, H. Bracq, J. P. Canciani, M. Allouis, J. M. Babut, The treatment of upper femoral unicameral bone cysts in children by Ender's nailing technique, Rev. Chir. Orthop. Reparatrice. Appar. Mot., 67 (1981), 147-149

${ }^{20}$ A. Roposch, V. Saraph, W. E. Linhart, Flexible intramedullary nailing for the treatment of unicameral bone cysts in long bones, J. Bone Joint Surg. Am., 82 (2000), 1447-1453

${ }^{21}$ F. Santori, S. Ghera, V. Castelli, Treatment of solitary bone cysts with intramedullary nailing, Orthopedics, 11 (1988), 873-878
${ }^{22}$ C. H. Chang, R. P. Stanton, J. Glutting, Unicameral bone cysts treated by injection of bone marrow or methylprednisolone, J. Bone Joint Surg. Br. 84 (2002), 407-412

${ }^{23}$ M. Amling, M. Werner, M. Posl, H. Ritzel, H. Welkerling, J. V. Wening, Solitary bone cysts, Morphologic variation, site, incidence and differential diagnosis, Pathologe, 17 (1996), 63-67

${ }^{24}$ L. C. Johnson, R. G. Kindred, The anatomy of bone cysts, J. Bone Joint Surg., 40 (1958) 1440-1448

${ }^{25}$ S. Komiya, K. Minamitani, Y. Sasaguri, S. Hashimoto, M. Morimatsu, A. Inoue, Simple bone cyst, Treatment by trepanation and studies on bone resorptive factors in cyst fluid with a theory of its pathogenesis, Clin. Orthop. Relat. Res., 287 (1993), 204-211

${ }^{26}$ J. Yu, S. S. Chang, S. Suratwala, W. S. Chung, P. Abdelmessieh, H. J. Lee, J. Yang, F. Y. Lee, Zoledronate induces apoptosis in cells from fibro-cellular membrane of unicameral bone cyst (UBC), J. Orthop. Res., 23 (2005), 1004-1012, doi:10.1016/j.orthres.2005.02.012

${ }^{27}$ B. D. Snyder, D. A. Hauser Kara, J. A. Hipp, D. Zurakowski, A. C. Hecht, M. D. Gebhardt, Predicting fracture through benign skeletal lesions with quantitative computed tomography, J. Bone Joint Surg. Am. 88 (2006), 55-70, doi:10.2106/JBJS.D.02600

${ }^{28}$ A. Ekkernkamp, A. Lies, P. Ostermann, Simple bone cysts treated by continuous decompression with screws, J. Bone Joint Surg. Br., 77 (1995), 210

${ }^{29}$ A. Roposch, V. Saraph, W. E. Linhart, Treatment of femoral neck and trochanteric simple bone cysts, Arch. Orthop. Trauma Surg., 124 (2004), 437-442, doi:10.1007/s00402-004-0702-5

${ }^{30}$ J. J. Masquijo, E. Baroni, H. Miscione, Continuous decompression with intramedullary nailing for the treatment of unicameral bone cysts, J. Child. Orthop., 2 (2008), 279-283, doi:10.1007/s11832008-0114-0

${ }^{31}$ H. Y. Hou, K. Wu, C. T. Wang, S. M. Chang, W. H. Lin, R. S. Yang, Treatment of unicameral bone cyst: a comparative study of selected techniques, J. Bone Joint Surg. Am., 92 (2010), 855-862, doi:10.2106/JBJS.I.00607 